\title{
Copyright Infringement for Academic Authorship in Uganda: Implications on Exemptions of Fair Use for Educational Purposes in Universities
}

\author{
Elisam Magara \\ Department of Records and Archives Management, East African School of Library and Information Science, Makerere University, Uganda
}

Copyright $(2016$ by authors, all rights reserved. Authors agree that this article remains permanently open access under the terms of the Creative Commons Attribution License 4.0 International License

\begin{abstract}
Like any other property, copyright as a form of Intellectual Property must be respected, and remunerated to address the socio-economic needs of society. Notwithstanding the different licensing systems and copyright protection avenues, educational and information institutions have continued to advocate for open access to information resources, under the legal exceptions for fair use. A survey using a self-administered questionnaire was conducted in educational institutions, libraries and archives in Uganda to assess the state of copyright infringement in Uganda. This paper recognizes a continued advocacy to open access to information resources, under the legal exceptions of fair use for educational purposes. Nevertheless, the uncontrolled reproduction of copyright works in educational institutions and information institutions, have contributed to copyright infringement robbing authors of their potential economic earnings and limiting their academic innovativeness and creativity. This paper attempts to underpin a need for a strategy to balance copyright protection and access to information. Thus, a strategic alliance by the Collecting Society, government, universities and right holder organisations to work together and institute a programme to address copyright protection and access to information is pertinently required.
\end{abstract}

Keywords Copyright Infringement, Intellectual Property, Licensing Systems, Copyright Protection, Uganda Copyright, Copyright Collecting Societies, Academic Authorship, Fair use for Educational Institutions, Libraries and Archives

\section{Introduction}

Copyright is a form of Intellectual Property that grants authors and artists control over use of their creations for defined periods of time and limits, and who may copy, change, perform, or share those creations [1]. According to the Centre for Genomic Regulations [2], Intellectual
Property is divided into two categories: Industrial and Copyright property. Industrial property includes inventions (patents), trademarks, industrial designs and geographic indications of source. A patent is an exclusive right granted for an invention, which is a product or a process that provides, in general, a new way of doing something, or offers a new technical solution to a problem. It provides protection for the owner, so that the invention cannot be commercially made, used, distributed or sold without the patent owner's consent.

Copyright property includes inventions, literary and artistic works such as novels, instruction manuals, computer programs, song lyrics, newspaper articles and some types of database; drama (including dance or mime); music; art (including paintings, engravings, photographs, sculptures, collages, architecture, technical drawings, diagrams, maps and logos); layouts (used to publish a work, for a book); recordings (of a work, including sound and film) and broadcasts of a work [3]. Furthermore, a copyright protected work can have more than one copyright, or another intellectual property right, connected to it. For example, an album of music can have separate copyrights for individual songs, sound recordings, artwork, and so on. Whilst copyright can protect the artwork of your logo, you could also register the logo as a trade mark [4]. These rights can be licensed, transferred and/or assigned and therefore requires protection from infringement.

To help us understand Intellectual Property, Long [5] explains the concept from four arguments: historical, ethical, economic and information-based. He notes that the historical argument has a tainted past, where both patents and copyrights were grants of monopoly privilege for instance, the rights and mandates given to some organisations such as printing presses that acquired the rights from historical and castle origins in various governments.

The ethical argument is based on the fact that the Intellectual Property of any kind has to be justified as extension of the right of an individual to control his/her own life. Long's argument is that each stakeholder has and controls his own right. In fact, his question is "If you have 
acquired the information legitimately (say, by buying a book), then on what grounds can you be prevented from using it, reproducing it or trading it? Is this not a violation of the freedom of speech and press? To him, to enforce copyright laws is to prevent people from making peaceful use of the information they possess.

Indeed, Fisher [6] advances the above rights in three theories: incentive theory, optimising patterns of productivity and rivalrous invention. Fisher negates being extremist and bending on either side of argument when it comes to Intellectual Property. To him, those theorists bent on avoiding redundant inventive activity have problems of their own, while the theorists who seek to optimise patterns of productivity confront less severe informational problem. This is why Weber [7] contends that a good or just law is one where its enforcement brings about more pleasure than would exist without it. To him, the pleasure and pain considered here is not simply physical, but intellectual as well. Intellectual Property rights include the right to control and derive the benefits from something one has invented, discovered or created.

\section{Copyright Regime in Uganda}

Uganda's legal system traces its origins to colonial times under British rule. Prior to Uganda's independence in 1962, the Intellectual Rights laws of Britain were already being applied to Uganda [8]. Uganda's copyright environment has for a number of years guided trademarks (1953), the Copyright Act of 1964, United Kingdom Designs (Protection) Act (1937) (as amended in 1962 provides that UK design registration automatically extends to Uganda) and until 1991, Uganda's Patent Law provided for registration of UK patents in Uganda. The Patent Law was repealed in 1991 by the Patents Act, 1993, Cap. 216. The Patents Act recognises patents granted under the Harare Protocol, which is administered by the African Regional Industrial Property Organisation (ARIPO) and in respect of which Uganda is a designated state. It permits the registration of ARIPO patents and patents issued by other member countries with minimal examination [9]. Article 26 of the Constitution of the Republic of Uganda [10], prohibits deprivation of private property. It reads in part: "No person shall be compulsorily deprived of property or any interest in or right over property of any description [...].". Currently, Uganda has the following principal Intellectual Property laws: Copyright and Neighbouring Rights Act (2006), Patents Act (1993), The Patents (Amendment) Act, 2002 (incorporates the Patent Cooperation Treaty (PCT) system into domestic law) and Trademarks Act (2010). Since Intellectual Property is cross cutting, there are several legislations and policies that address it under the different sectors that address copyright i.e. National Trade Policy (2007), National Industrial Policy (2008), National Science, Technology and Innovation Policy (2009), Uganda National Culture Policy (2006), Computer Misuse Act (2011) and the Uganda Electronic Transactions Act (2011).

The Copyright and Neighbouring Rights Act (2006) [11] and the Copyright and Neighbouring Rights Regulations (2010) [12] guide the Copyright Regime in Uganda. The Copyright and Neighbouring Rights Act provides for the protection of literary, scientific and artistic intellectual works and their neighbouring rights; and provides for other related matters. The Act applies to any work which has not yet fallen into the public domain where the work is created by a citizen or resident of Uganda; first published in Uganda, irrespective of the nationality or residence of the author; created by a person who is a national of or resident or; first published in a country referred to in section 81 (reciprocal arrangement). Section 5 describes the works eligible for protection to include: a) Literary, scientific and artistic work like articles, books, pamphlets, lectures, addresses, sermons and other works of a similar nature; e) computer programmes and electronic data banks and other accompanying materials; i) derivative work which by selection and arrangement of its content, constitute original work; any other work in the field of literature, traditional folklore and knowledge, science and art in whatever manner delivered known or to be known in the future and translations, adaptations and other transformation of pre-existing works under subsection (1); and collections of pre-existing works like encyclopedia and anthologies; which by selection and arrangement of their contents constitute original works, shall be protected as original work.

Section 9 to 10 of the Act provides for the types of rights; the economic and moral rights. The economic rights (section) include rights to publish, produce or reproduce the work; to distribute or make available to the public the original or copies of the work; to perform the work in public; to communicate the work to the public; and to commercially rent or sell original or copies of the work. The moral rights on the other hand (section 10) cover a person's right to claim authorship of a work and to object to any distortion, mutilation or other modification of the work, or any other derogatory action in relation to the work, that would be prejudicial to the author's honour or reputation. Some of these infringements include economic, moral and neighbouring or other rights. Moral rights are recognised independently of the author's economic rights and they continue even in the case of transfer of the economic right [13]. However, after the expiration of economic rights, the author ordinarily no longer has the right to object to reproduction, sale or making of a derivative work. Neighboring rights (Section 21) are rights attached to the auxiliary role done for the fulfilment of literary or artistic works, with the diminishing of distance in the publication of works; e.g. a book into plays and movies, or a song or musical piece used in a musical drama. The Related Rights also cover those of performing artists in their performances, producers of phonograms in their recordings, and those of broadcasters in their radio and television programs.

\section{The Institutional Framework in Copyright Protection and Use}

In Uganda, the mandate of copyright and other 
neighbouring rights is under the Ministry of Justice and Constitutional Affairs [14] implemented by the Uganda Registration Services Bureau (URSB). The mandate of the Ministry is "to promote and facilitate effective and efficient machinery capable of providing a legal framework for good governance and delivering legal advice and services to the Government, its allied institutions and the general public". The URBS [15] is responsible for the following functions; Business Registration - documents, intellectual property rights - includes registration of patents, industrial designs, trademarks, service marks and Copyright and Neighbouring Rights as guided by the Copyright other Neighbouring Rights Act, 2006. The collecting society is catered for under Part VII of the Act.

According to the Act, a copyright collecting agency created by copyright law shall engage in collective rights management. Collecting societies have the authority to license copyrighted works and collect royalties as part of compulsory licensing or individual licenses negotiated on behalf of its members. Collecting societies collect royalty payments from users of copyrighted works and distribute royalties to copyright owners. Collecting Management Organisations CMOs are set up and owned by rights holders. Currently there are three CMOs in Uganda including: Uganda Performing Rights Society for music rights; Uganda Federation of Movie Industries for audio-visual rights and; Uganda Reproduction Rights Organisation (URRO) for literary, artistic and scientific works.

Copyright in Uganda is controlled by The Uganda National Bureau of Standards [UNBS], which established the standard of branding intellectual property. Other bodies like Uganda Law Reform Commission, Ministry of Justice and Constitutional Affairs, Uganda Law Society, Courts of Judicature (Commercial Court), Ministry of Tourism, Trade and Industry and Uganda National Council for Science and Technology (UNCST) play a crucial role in copyright policy formulation and implementation. For example, one of the strategic objectives of UNCST [16] is to strengthen intellectual property management.

In 2012, Uganda Textbook, Academic and Non-Fiction Authors (UTANA) was formed with the aim of providing a forum for advocacy services to its members for continuous interaction, promotion and protection of their rights, promote the recognition and fair remuneration of authors, and respect for their rights and provide a one stop centre for members' progressive economic development through partnerships and collaborations. UTANA facilitates copyright management in collaboration with URRO.

Despite the need for copyright protection, access and use of the materials is often required for educational and research purposes. This is facilitated by a number of legislations in Uganda that include the National Records and Archives (NRA) Act 2001, the Access to Information Act 2005, the Electronic Transactions Act 2011 and the National Library Act (NLA) 2003. Whereas the NLA demands the deposit of books and documents that are published in Uganda and made available to the public, the NRA Act provides that the provision of copies of public archives does not involve the transfer of any copyrights in them to the recipients (Article 18). Furthermore, the National Council for Higher Education is set to promote and develop a forum for processing and dissemination of information on higher education for the benefit of the people [17]. This role is supported by the Consortium of Uganda University Libraries (CUUL), whose strategic objectives are, among others, to promote co-operative information processing, storage, preservation, dissemination, as well as information and communication technology (ICT) development and application.

Libraries, archives, universities and other institutions of higher learning are the major custodians of copyright works, both academic and non-fiction, including documents such as books, journal articles, conference papers, reports, theses, teaching materials, research notes, research data, etc. . Libraries are pillars on which research in universities revolve by providing access to information. Thus, libraries and archives aim at managing, dissemination and preservation of these works. This, as advanced by Ngulube (2007) in Namaganda [18], help scholars use research to generate further research, models and new knowledge. In an effort to ensure access to various resources, libraries have adopted many avenues such as legal deposit of publications, institutional repositories, and open access publishing through creative commons, among other ways.

To ensure increased access to deposited materials in libraries, archives and educational institutions, institutional repositories that collect, organise and allow the retrieval of scholarly articles and books, theses and dissertations, conference proceedings and technical reports in electronic format have been set up. Through CUUL, universities have advocated and facilitated electronic resources and the use of creative commons as a strategy to increase access to information and resource-sharing. However, whereas such work is used for educational and research purposes in the name of fair use, educational institutions, libraries and archives have not typically acquired copyright along with the materials. This challenge is accelerated by the use of electronic resources. For instance, while a recent policy by Makerere University [19] on submission of Theses and Dissertations in soft copies may reduce on the tedious digitisation process, it opens chances for copyright infringement. This is in addition to some researchers' fear to deposit in the institutional repository for fear of plagiarism or any content validation through peer-review processes.

\section{The Fair use Regime and Infringement of Copyright in Uganda}

Copyright has the same kind of commercial value as any other property that can take various forms, such as a sale, or a more restricted right to do something in relation to the subject matter of the right. According to the Copyright and other Neighbouring Rights Act, 2006, rights extend to the 
life of the author and 50 years after death; for joint authorship, during the life of the last surviving author and 50 years after the death of the last surviving author. Rights owned by a corporation extend 50 years from the date of first publication of the work. Work published anonymously or under a pseudonym extends for 50 years from the date of first publication. Where before expiration of the 50 years the identity of the author is known or is no longer in doubt, the economic right shall be protected during the lifetime of the author and 50 years after the death of the author. For computer programmes, the copyright is 50 years from the date of making the programme available to the public. For photographic work, the rights are protected for 50 years from the date of making of the work.

Authors can exploit their works themselves, and some can leave them to a third party, which involves the transfer of some or all the rights in the work to that third party. Indeed, the law provides that the owner of a copyright may assign his or her economic rights to a copyright to another person; license another person to use the economic rights in a copyright; transfer to another person or bequeath the economic rights in a copyright; or transfer for fair use like for educational purposes and to any Braille production unit or the Braille translation. The question that is of major concerns in this paper is the issue of fair use exemptions and limitations.

The current discussions at the World Intellectual Property Organisation (WIPO) focus on the possibility of new copyright exceptions and limitations treaties for libraries, archives and educational institutions. Interest groups such as the International Federation of Library Associations and Institutions (IFLA) advocate and favour new international treaties covering exceptions E.g. such as the Agreement on Trade-related Aspects of Intellectual Property Rights (TRIPS) [20]. Through its Copyright and Other Legal Matters Committee (CLM), IFLA advocates for access to information including the IFLA Internet manifesto [21], and the Declaration on Libraries, Information Services and Intellectual Freedom [22], Position on Copyright in the Digital Environment [23], Licensing Principles [23], Limitations and Exceptions to Copyright and Neighbouring Rights in the Digital Environment [24] and Copyright Limitations and Exceptions for Libraries and Archives [25].

According to IFLA [26], the economic rights of information providers [right owners] must be balanced with society's need to gain access to knowledge, a pivotal role played by libraries. This is in particular in the use of digital environment that has the potential to support access for all members of society, especially in developing countries and in disadvantaged groups. IFLA's concern is that the increased use of licensing and technological protection is distorting the balance towards commercial interests and away from information users. The argument here is that whereas it is a public interest to give authors an incentive to create, the laws should also encourage the dissemination of new knowledge. Indeed, IFLA acknowledges the need for creators of works to enjoy the right to control, and to be remunerated for subsequent dissemination, an incentive to enable authors to be motivated to spend their time and effort in creating valuable original expression. A significant number of creators (primarily academics) place a far higher value on dissemination of their creative work rather than direct reimbursement for the use of the work. The other concern by IFLA is that the recent expanded use of technological protection measures and the emerging licensing environment are converging to shift the use of copyright materials to a pay per view environment, which limits access to those who can pay. IFLA is also critical of contractual licensing that seems to be not favourable for digital environment, but advocate a license to take the form of a written contract or agreement between the library and the owner of the rights to distribute digital information. This argument seems to be what long [27] is warning us of being extremist, which he calls the ethical that combines with historical (because of the role libraries serve) argument to become too extremists. Note that the right holders range from the publishers, authors, illustrators, translators, etc. Indeed, in national copyright legislation, exceptions to copyright and related rights allowed in the Berne Convention and endorsed by the WIPO treaties all provide clear definition of copyright protection, the exemptions and limitations of fair use.

The other issues advanced by IFLA (2004) and IFLA-CLM [28]) including the need for laws to address resource sharing, inter-library lending, public lending, preservation and conservation, licencing and exemptions are covered in various national legislations and international treaties. For instance, the WIPO Copyright Treaty (WCT), the WIPO Performance and Phonograms Treaty (WPPT), and TRIPS all provide for exclusive rights with respect to the authors' works including the right of reproduction, adoption, broadcasting, public performance, communication and distribution to the public, subject to certain limitations and exemptions [29]. However, public lending where materials are to be distributed goes beyond the exemption and limitations for fair use.

Public Lending Right (PLR) is the right of authors to receive payment for free public use of their works in libraries. PLR has been around since the 1940s: Denmark (1946), Norway (1947), Sweden (1954), UK system (1979) and now 33 nations have PLR systems. There are three categories of PLR (a) copyright-based; (b) as a separate remuneration right recognised in law; (c) as part of state support for culture. Some countries incorporate a combination of all three approaches. In all the three, issues of PLR [30] go beyond information based argument. It integrates more of economic and incentives to the right holders as advanced by Falvey [31], Ring and Fisher [32]. In fact, Hyait [33] asserts that most proponents contend that PLR legislation is an integral part of copyright law, while opponents maintain that PLR legislation is hardly a consideration of copyright law. To Hyait, once an idea is fixed into a tangible medium of expression, copyright law grants to the creator or his assigns the exclusive right to reproduce copies for a term fixed by 
statute. Here, the owner has the exclusive right not only to reproduce, but also to derive from, distribute, perform, or display the copyrighted material. Indeed, Hyait sights other cases, that have additional rights, known as droit moral (moral right), which include the right to withdraw a publication if it no longer expresses the views of the author and the right to be known as the author. Thus, public lending does not stop any function from library lending; inter library loan and document supply in digital and print forms; or enable use of orphan works; acquisition of e-books from publishers. The discussion on increased access to copyright works has been going on in Uganda since 2005 through the 2005 Africa Copyright Forum Conference in Kampala which called for laws to allow increased access to copyrighted materials for educational use [34]. This is to allow learners to easily access learning content, including learners with special needs to easily access translations, adaptations and conversions into different formats. In order to balance easy access of copyrighted materials for educational purposes, and the interests of creators and consumers, several African countries are revising their legislation regarding trade-related aspects of intellectual property rights agreements to rhyme with the provisions of the Berne Convention Treaty. The Treaty deals with the allowance of 'fair use of copyrighted works, including the legitimacy of the use of literary or artistic works for educational purposes in publications, broadcasts and sound or visual recordings, if such use is compatible with fair practice [35]. Here, governments may also allow limited reproduction of copyrighted works in specific circumstances if this does not infringe either the normal exploitation of the work or the legitimate interests of the author. The Treaty also provides developing countries with the carefully delineated option of compulsory licensing, in order to purchase or copy imports of literary or artistic works from abroad, in order to promote educational access.

Other advocates of increased access to copyright works was initiated by the Berkman Center for Internet and Society [36], and eIFL.net, moderated and improved with recommendations from the East African School of Library and Information Science (EASLIS) in an attempt toing at developing learning materials for Copyright course for Librarians. The course is aimed at course to ensuring improved access to information by libraries and librarians. This attempt was made to ensure that custodians including librarians understand and address the balance of authors' rights in meeting the educational institutions, libraries and custodians needs of access to information in dealing with the fair use.

As a principle, libraries, archives and their patrons have rights of fair use under Copyright Law and the international copyright agreements including Berne Convention Amended on September 28, 1979, entry into force on November 19, 1984 [37]. Some of these rights include: Criticism, comment, news reporting, teaching, scholarship and research. In fact, the Copyright and other Neighbouring Rights [38], Act, 2006, fair use of a protected work in its original language or in a translation shall not be an infringement of the rights of the author and shall not require the consent of the owner of the copyright (section 15) where:

- the production, translation, adaptation, arrangement or other transformation of the work is for private use only; a quotation from a published work is used in another work including a quotation from a newspaper or periodical in the form of press summary;

- a published work is used for teaching purpose to the extent justified for the purpose so far as the use is compatible with fair practice and acknowledgement is given to the work and the author;

- the work is communicated to the public for teaching purposes in so far as the use is compatible with fair practice and acknowledgement is given to the work and the author;

- the work is reproduced, broadcast or communicated to the public with acknowledgement of the work;

- any work that can be heard is reproduced or communicated to the public by means of photograph, audio-visual work or broadcast to the extent justified for the purpose when reporting on current events;

- any work of art or architecture in a photograph or an audio-visual or television broadcast is reproduced and communicated to the public where the work is permanently located in the public place or is included by way of background or is otherwise incidental to the main object represented in the photograph or audio-visual work or television broadcast;

- for the purpose of current information, a reproduction in the press, broadcast or communication to the public is made (a political speech, a speech during any judicial proceeding; or an address, lecture, sermon or other work of a similar nature delivered in public);

- for the purpose of a judicial proceeding, work is produced;

- subject to conditions prescribed by the Minister of Justice;

- any work is transcribed into Braille or sign language for educational purposes of persons with disabilities.

Indeed, the character of the use, the nature of the material to be copied, amount and importance of the part copied and effect on market of the works remain an important factor for consideration in protection of copyright. However, it is important to note that lack of controlled open access to use of copyright works may lead to copyright infringement. According to the Act, Section 46, Copyright infringement applies to any use of copyrighted work without the permission of the author unless it falls into a legal exception or is otherwise excused. Accordingly, the infringement of copyright or neighbouring right occurs where, without a valid transfer, licence, assignment or other authorisation under this Act a person deals with any work or performance 
contrary to the permitted free use and in particular where that person does or causes or permits another person to reproduce, fix, duplicate, extract, imitate or import into Uganda otherwise than for his or her own private use; distribute in Uganda by way of sale, hire, rental or like manner; or exhibit to the public for commercial purposes by way of broadcast, public performance or otherwise. For any exemption to be considered relevant and acceptable, it is important to establish the circumstances and justification and extent of the infringement on the copyright works.

\section{The Problem Statement}

Whereas several countries and interest groups favour new international treaties covering copyright exceptions, authors are concerned that if introduced, such treaties will weaken copyright protection and remove important sources of income which may have been previously generated by copyright licences. The Copyright and other Neighbouring Rights Act, 2006 provides for legislation with regards to intellectual rights. There are, however, some key concerns that limit authors from fully enjoying the benefits of authorship such as an unpredictable environment and infringements on academic and non-fiction works. Notwithstanding the different licensing systems and copyright protection avenues, custodians of copyright works have continued to advocate for open access, creative commons and institutional repositories. However, increased access to materials without restrictions has resulted in copyright infringement, especially in the works that fall into legal exceptions of fair use for educational purposes, and in libraries. Indeed, at the 28th meeting of the Standing Committee on Copyright \& Related Rights (SCCR) in Geneva, 2014, member states "agreed to disagree" on any conclusions on copyright exceptions for libraries and archives [39]. A study to provide an opinion of the extent of copyright infringement is therefore crucial to ensure that increased access and use of copyright works does not limit the owner's expected rights.

Aim: To assess the state of copyright infringement in Uganda for increased use of academic and non-fiction works.

\section{Objectives of the Paper}

i. To establish the nature and forms of copyright infringement for academic and non-fiction works in Uganda.

ii. To identify the circumstances for copyright infringement for academic and non-fiction works in Uganda.

iii. To assess the opinions of the custodians on the copyright infringement for academic and non-fiction works in Uganda.

iv. To provide strategic/policy options for delimiting copyright infringement for academic and non-fiction works in Uganda

\section{Methodology}

The study was conducted within Uganda in organisations that keep and manage information susceptible to copyright infringement. The respondents comprised of records officers, librarians, customer services, examiner patents, publishing managers, data entry clerks and information offers, among others. Majority of respondents worked in libraries, business records centres, administration, IPR office, business registration services, policy planning, procurement, resource centres, reference centres, and registries. Majority of respondents were degree holders (34/45), Diploma (6/45) and Master's Degree (5/45). Majority of the respondent's qualification were in Library and Information Science, Records and Archives Management and Law. Two people had qualifications in Procurement and Human Resource Management. All the respondents had a direct connection with the storage, management, access and use of information materials in the respective organisation. Majority of them were at a supervisorial level and had staff under them. Physical visits were made to respective institutions by the researcher and/or the research assistants. All research assistants had knowledge of library and information science. Prior to the study, the researcher used available literature to identify the variables to represent specific traits/variables concerning the subject of study to be measured. This was useful in evaluating respondents' opinion on important features using a likert scale with the ranks of 1 to 5 , where 1 is the least favoured and 5 is the most favoured variable/statement. A self-administered questionnaire required the respondents to either tick or fill in gaps as required. The open questions were analysed based on the themes of discussion and were integrated in the quantitative responses. Extra readings from newspapers, blogs on websites, journal articles and review of literature was done to fill the knowledge gaps.

\section{Findings}

\section{The Nature and Forms of Copyright Infringement in Uganda}

One of the objectives of this study was to establish the nature and forms of copyright infringement. The study identified the nature of copyright practices and the forms of copyright infringement as discussed in the sections that follow.

\section{a) Nature of Copyright Infringement Practices}

Respondents were asked to comment on how the organisations are handling the practices that tend to influence copyright infringements.

i. Photocopying and reproduction of books: This is a common vice and is done even to the whole book (information material). In libraries, users normally borrow and take the photocopy outside the library. There is no limitation when 
the photocopy is done outside the library. The use and amount of photocopying depends on the individual and no follow up system as one librarian noted, "it is done at one's own risk". Justification for this practice is based on the fact that students need to photocopy for academic purposes. This does not, however, warrant the students to photocopy without permission from the owner, one respondent noted. In fact in some libraries, students are not permitted to photocopy without the lecturers recommending the areas of interest. It was noted that where photocopying is done as a business, there is no control of photocopying and currently no system to follow. In other cases, photocopy is done for purposes of preservation, especially those documents needed for organisational functions like policy statements and manuals and rare books. In archives and records institutions, photocopying depended on assess of the storage media and limited by confidentiality and security of information contained in the documents.

ii. Scanning of books: The study responses did not associate scanning works to copyright infringements. To them, scanning was done to allow storage and use of materials in soft form. There was, however, no control over this practice. It was noted that some institutions like ministries scan documents for uploading on the Internet and intranet for public use.

iii. Digital/electronic or Internet downloads: It was established that Internet downloading was heavily done on a very large scale, mostly done individually and with no procedure followed. Attitudes among respondents imply that downloading was considered free for whoever needed it. In universities, especially those allowed by different databases and e-Journals, lecturers, researchers and students do a lot of downloading.. There was observed lack of restrictions and no control in the use of downloads. Use of passwords and access procedures have helped in the control of downloads, especially in the use of electronic resources in educational institutions. However, in some cases, the passwords were open thus making the materials open to the public.

iv. Microfilming: These services are not available in most of the institutions and thus not practised in organisations outside the academics. This practice was exhibited in Makerere University, especially in dissertations and thesis. This however was limited to abstracts.

v. Braille materials: These were not common in most libraries and there was no policy on the use of Braille in the universities.

\section{b) Common Forms of Copyright Infringement}

Respondents were asked to indicate the common forms of copyright infringement Uganda. Using a likert scale on preference on the predetermined forms of copyright infringement, Plagiarism and piracy came out outstanding as presented in table 1 below.

Table 1. Forms of Copyright Infringement in Uganda

\begin{tabular}{|c|c|c|c|c|c|}
\hline Form of Copyright Infringement & 1 & 2 & 3 & 4 & 5 \\
\hline $\begin{array}{c}\text { Plagiarism (Using someone else work } \\
\text { without giving proper credit }\end{array}$ & 3 & 3 & 9 & 8 & 22 \\
\hline $\begin{array}{c}\text { Piracy (The massive unauthorised } \\
\text { reproduction) }\end{array}$ & 3 & 9 & 5 & 11 & 17 \\
\hline $\begin{array}{c}\text { Peer to peer network or sharing of } \\
\text { downloads }\end{array}$ & 3 & 9 & 6 & 16 & 11 \\
\hline $\begin{array}{c}\text { Commercial pirates that engage in } \\
\text { commercial printing }\end{array}$ & 0 & 13 & 9 & 10 & 13 \\
\hline The culture creative infringement & 0 & 11 & 12 & 3 & 19 \\
\hline $\mathrm{N}=45$ & & & & & \\
\hline
\end{tabular}

Plagiarism has been described by the media as the major cause of academic decline in Uganda [43]. In fact, Ithenticate [40] cautions of serious legal repercussions of plagiarism, as "One cannot use another person's material without citation and reference as some may be deemed a criminal offense, possibly leading to a prison sentence". Indeed, some universities have taken disciplinary measures as reported by Prof. Katunguka in the Weekly Observer [41] that "During my tenure, we have discontinued three $\mathrm{PhD}$ students when it was found that their work was substantially copied from other people's work. But you can't eliminate plagiarism completely". The Weekly Observer instances where on lecturer lifted whole paragraphs, word by word, phrase by phrase, from a thesis without acknowledging the source of his information as is the norm in academic practice.

Copyright infringement was also cited the case of Prof. George. W. Kakoma v The Attorney General Civil Suit No.197 of 2008 Judgment Date: 29 July 2010 [42]. The plaintiff sought recovery of damages, compensation and royalties for infringement of copyright, for a permanent injunction restraining further infringement and costs of the suit. The facts were that:

In early 1962, an open competition for composing of Uganda's National Anthem was advertised; that no conditions were attached to the would-be winning entry. Kakooma was declared the winner and was given a token of Shs 2,000/= as a mark of appreciation. A year later, the government realizing this was copyright material, wrote asking him to surrender his copyright to them, he referred the matter to his lawyers who responded and wrote back to the Government demanding a fee of $£ 5000$ only before he could sign off his copyright. That the political turmoil that followed left the matter unsettled until Amin came to power. That in January 1975 he went into self-exile with his family and taught at Kenyatta University until NRA government came to power in 1986, when there was the 
chance to have the matter raised again. That the Ministry of Justice took up the matter and presented a Cabinet Memo which was turned down on a flimsy ground that compensating him would create a precedent. Although this is in music, but is also common in literacy works, especially commissioned works, joint authorships and derivative works [42].

In one of the recent raids by Uganda Reproduction Rights Organisation (URRO), a collective management body authorised by Uganda Registration Services Bureau (URSB) to enforce the copyright of books to save the publishing industry, some books like Nikolai Gogol's The Government Inspector, George Orwell's Animal Farm have been found on a book peddler's stall in the market being sold at lower prices than in the bookshop [43]. For instance Julius Ocwinyo's Fate of the Banished costs Shs18, 000 in a bookshop but one can bargain it down to 10,000 when it is a pirated copy on the street. About 80,000-copies of pirated books were netted during a joint operation between publishers and the Uganda Registration Services Bureau (URSB) that covered bookshops, printers, homes and streets throughout the country. According to Charles Batambuze, the Executive Director of the URRO, the impounded books are part of a racket that has seen the market flooded with pirated books.). Such practice disrupts the learning process, authors and publishers lose business despite incurring all the expenses and government loses revenue, which eventually frustrates investment in publishing.

Peer to peer network sharing and distribution of copies and downloads increases access to information but also promotes copyright infringement. Although no case was sighted in Uganda, it has happed in the region. In Kenya, a recent raid by the Reproduction Rights Society of Kenya (Kopiken) [44] in Universities indicated massive photocopying although administration had denied it was being done therein. According to Kenya's Copyright Act, 2001[45], section 26 (1) (h), the direction of work is mandated by or under the control of the Government... as may be prescribed, where the reproduction is in the public interest and no revenue is derived there from.

In Uganda, educational institutions, too, have facilitated copyright infringement. For instance, Makerere University, which has the biggest academic library in Uganda, owns and manages photocopiers within the library and also provides other reprographic services, at a fee, such as microfilming and digitisation. However, some authors are not willing to pursue their rights because of apathy, fear, lack of money to pursue a legal case, and balancing the gains from pursuing court suits against popularity. In UK, the copyright infringement petition filed by Oxford and Cambridge University Press with Fancis and Tailor against DU and Rameshwari photocopy services in D-School, challenging the practice of photocopying course material, left varsity students red faced [46]. The petition said that photocopying allows students cheap access to otherwise expensive material. The petition brought under the lens, the set norms and definition of 'mass circulation'. Indeed, Danish [46] cites other examples that in 1991, eight publishers filed a lawsuit against Kinko's Graphic Corp in USA on similar grounds. The case against Kinko's led to the formation of intermediary agencies which take care of copyright licensing of academic work, which the Collecting Society and Right Holders Organisation are advocating for.

\section{Types of works that face infringement}

Using a likert scale with the ranks of 1 to 5 , respondents were asked to rate the following academic and non-fiction works that face copyright infringement. The number of respondents for each format of works under each rank is presented in table 2 , where 1 is the least faviored and 5 is the most favoured.

Table 2. Rate of infringement on the formats of works in academic or non-fiction works

\begin{tabular}{|c|c|c|c|c|c|}
\hline & \multicolumn{5}{|c|}{$\begin{array}{c}\text { Ranking (1 being the least favoured } \\
\text { and 5 most favoured })\end{array}$} \\
\hline Formats of works & 1 & 2 & 3 & 4 & 5 \\
\hline Textbooks & 7 & 4 & 4 & 7 & 23 \\
\hline $\begin{array}{c}\text { Encyclopedia, dictionary, } \\
\text { directories or anthologies }\end{array}$ & 36 & 2 & 2 & 2 & 3 \\
\hline $\begin{array}{c}\text { Biographies and } \\
\text { autobiographies }\end{array}$ & 24 & 13 & 1 & 3 & 4 \\
\hline Scholarly articles & 18 & 7 & 5 & 1 & 14 \\
\hline Policy, manuals and plans & 11 & 9 & 7 & 5 & 13 \\
\hline Lecture notes, sermons, essays & 15 & 6 & 7 & 5 & 12 \\
\hline Braillie materials & 25 & 7 & 3 & 10 & 0 \\
\hline $\begin{array}{c}\text { Company/organisational } \\
\text { reports and manuals }\end{array}$ & 12 & 9 & 10 & 4 & 10 \\
\hline Thesis and dissertations & 7 & 4 & 6 & 13 & 15 \\
\hline $\begin{array}{c}\text { Conference/workshop and } \\
\text { seminar proceedings and } \\
\text { reports }\end{array}$ & 22 & 4 & 5 & 6 & 8 \\
\hline N=45 & & & & & \\
\hline
\end{tabular}

From the above, it is clear that most of the infringement is done in textbooks with (23/45), Thesis and dissertation $(15 / 45)$ and scholarly articles (14/45). This study acknowledges that uncontrolled photocopying, piracy, digital and internet downloading have contributed to massive plagiarism and duplication of authors' work, thus robbing them of their potential earnings and limiting their innovativeness. As a result, authors are deterred from devoting time to producing more content. Textbooks, theses, dissertations and scholarly articles were ranked high as forms of piracy. Although libraries and their patrons have rights of fair use under Copyright Law and the International copyright agreements, which allow them to use the materials for criticism, comment, news reporting, teaching, scholarship and research, these have clearly been abused. What is important is the character of the use, the nature of the material to be copied, amount and importance of the part copied and effect on market of the works. These remain an important factor for consideration in protection of copyright. 
It should be noted that electronic access increases opportunities and easier access to others' works and wider dissemination. There was no responses on Braille because section 15(1)(k) of the Copyright and Neighbouring Rights Act of 2006 [48states that works 'transcribed into Braille or sign language for educational purpose of persons with disabilities' are covered by the fair use exception. In fact, the Marrakesh Treaty facilitates access to published works for persons who are blind, visually impaired or otherwise print disabled. Article 4(2)(a) of the Treaty states that "Authorized entities shall be permitted, without the authorization of the copyright holder, to make an accessible format copy of a work, obtain from another authorized entity an accessible format copy, and supply those copies to beneficiary persons by any means, including by non-commercial lending or by electronic communication by wire or wireless means, and undertake any intermediate steps to achieve those objectives, when all of the following conditions are met:

i. the authorized entity wishing to undertake the said activity has lawful access to that work or a copy of that work;

ii. the work is converted to an accessible format copy, which may include any means needed to navigate information in the accessible format, but does not introduce changes other than those needed to make the work accessible to the beneficiary person;

iii. such accessible format copies are supplied exclusively to be used by beneficiary persons; and

iv. the activity is undertaken on a non-profit basis.

\section{Reasons and Circumstances for Copyright Infringement in Uganda}

Respondents were required to indicate the circumstances or reasons under which photocopying/scanning/duplicating is mostly done in various institutions.

\section{a) Circumstances under which infringement is mostly done}

Using a likert scale with the ranks of 1 to 5 , respondents were asked to rate the pre-determined circumstance under which infringement is mostly done. The number of respondents for each of the circumstance under each rank is presented in table 3 , where 1 is the least favoured and 5 is the most favoured. Table 3 shows the users' opinion.

The table shows that the need for general use and the existence of electronic means of communication like the email and intranet have facilitated copyright infringement especially for academic purposes. The Copyright and other Neighbouring Rights Act, 2006, provides that fair use of a protected work in its original language or in a translation shall not be an infringement of the rights of the author and shall not require the consent of the owner of the copyright where: the production, translation, adaptation, arrangement or other transformation of the work is for private use only; a quotation from a published work is used in another work including a quotation from a newspaper or periodical in the form of press summary; a published work is used for teaching purpose to the extent justified for the purpose so far as the use is compatible with fair practice and acknowledgement is given to the work and the author; the work is communicated to the public for teaching purposes in so far as the use is compatible with fair practice and acknowledgement is given to the work and the author.

Table 3. Circumstances under which infringement is mostly done

\begin{tabular}{|c|c|c|c|c|c|}
\hline & \multicolumn{5}{|c|}{ Rankings } \\
\hline Circumstances of infringement & 1 & 2 & 3 & 4 & 5 \\
\hline $\begin{array}{l}\text { I always do photocopying for loaning } \\
\text { services }\end{array}$ & 26 & 4 & 3 & 3 & 9 \\
\hline Preservation & 18 & 6 & 5 & 1 & 15 \\
\hline Distribution to clients & 18 & 5 & 3 & 3 & 16 \\
\hline $\begin{array}{c}\text { For general use, e.g. reserves, documentary } \\
\text { delivery }\end{array}$ & 10 & 7 & 5 & 3 & 20 \\
\hline Course packs, classroom hand-outs & 15 & 2 & 2 & 9 & 17 \\
\hline $\begin{array}{l}\text { Use in email, intranet/extranet/internet } \\
\text { posting }\end{array}$ & 20 & 8 & 0 & 1 & 16 \\
\hline $\begin{array}{l}\text { Posting e-reserves, course management } \\
\text { systems, e-course packs }\end{array}$ & 18 & 9 & 3 & 1 & 14 \\
\hline $\begin{array}{l}\text { When I have failed to acquire the original } \\
\text { copy of the book }\end{array}$ & 11 & 11 & 10 & 2 & 11 \\
\hline $\begin{array}{l}\text { When I want to use large sections of the } \\
\text { book I can't finish reading }\end{array}$ & 17 & 7 & 12 & 3 & 6 \\
\hline Share with co-workers & 9 & 15 & 6 & 9 & 6 \\
\hline Share content electronically & 11 & 7 & 5 & 4 & 18 \\
\hline Email to co-workers or post on intranet & 9 & 2 & 9 & 0 & 25 \\
\hline Provided I give the author credit & 24 & 13 & 3 & 5 & 0 \\
\hline $\begin{array}{l}\text { The fair use exemption allows me to legally } \\
\text { copy small amounts of someone's work }\end{array}$ & 21 & 10 & 3 & 0 & 11 \\
\hline
\end{tabular}

b) Knowledge and attitudes of respondents on the circumstances of copyright infringement

Respondents were required to indicate what best describes the knowledge and attitude people have on copyright infringement, as entailed in Table 4 below. Using a likert scale with the ranks of 1 to 5 , respondents indicated their presumed knowledge and attitude as reported under each rank is in table 4 , where 1 is the least favoured and 5 is the most favoured.

Table 4 shows that piracy is rampant yet there seems to be nothing is being done about it, which and this greatly affects the publishing industry and interns the academics and non-fiction authors. This vice tends to kill authors' initiatives, and creativity and, robs/limits writers' them of earnings from their original work. Reasons for copyright infringement include the status of institutional copyright policies, varying publisher copyright policies, difficulty in obtaining author versions of publications, doubts about the quality of open access research, and fears regarding plagiarism, among others. 
Table 4. Knowledge and attitude on copyright infringement in Uganda

\begin{tabular}{|c|c|c|c|c|c|}
\hline \multirow[b]{2}{*}{ Presumed knowledge and attitudes } & \multicolumn{5}{|c|}{ Rankings } \\
\hline & 1 & 2 & 3 & 4 & 5 \\
\hline $\begin{array}{l}\text { I can report copyright infringement to people who have legal power to take } \\
\text { a decision }\end{array}$ & 18 & 12 & 6 & 2 & 7 \\
\hline $\begin{array}{c}\text { The Court may require me or my institution to pay fees when involved in } \\
\text { infringement }\end{array}$ & 12 & 3 & 7 & 4 & 19 \\
\hline Uncontrolled photocopying may contribute to massive plagiarism & 12 & 4 & 8 & 3 & 18 \\
\hline Piracy is rampant yet nothing is being done about it & 10 & 3 & 3 & 6 & 23 \\
\hline $\begin{array}{l}\text { Piracy greatly affects the publishing industry and intern the academics and } \\
\text { authors }\end{array}$ & 12 & 3 & 6 & 3 & 21 \\
\hline $\begin{array}{l}\text { Most of the people do photocopying unprofessionally without observing the } \\
\text { copyright policy }\end{array}$ & 12 & 2 & 5 & 5 & 21 \\
\hline $\begin{array}{l}\text { There is rampant duplication of other people's work without the author } \\
\text { gaining anything financially }\end{array}$ & 11 & 2 & 9 & 4 & 19 \\
\hline Piracy has deterred people from putting in time to author content & 14 & 3 & 7 & 5 & 16 \\
\hline Piracy kills initiatives , robs/limits writers' earnings from original work & 6 & 6 & 6 & 6 & 21 \\
\hline If piracy is not checked, it has a high level of motivation & 6 & 3 & 13 & 8 & 15 \\
\hline $\begin{array}{l}\text { The impact is not felt and thus it robs/limits writers' earnings from original } \\
\text { work }\end{array}$ & 9 & 6 & 7 & 15 & 8 \\
\hline Many people do not appreciate existence of any policy & 10 & 4 & 8 & 10 & 13 \\
\hline $\mathrm{N}=45$ & & & & & \\
\hline
\end{tabular}

Table 5. Ranking on the opinion regarding the practices of copyright infringement

\begin{tabular}{|c|c|c|c|c|c|}
\hline \multirow[b]{2}{*}{ Opinions } & \multicolumn{5}{|c|}{$\begin{array}{c}\text { Ranking (1 being strongly disagree and } 5 \text { being } \\
\text { strongly agree) }\end{array}$} \\
\hline & 1 & 2 & 3 & 4 & 5 \\
\hline Photocopying whole book is illegal & 12 & 1 & 3 & 5 & 24 \\
\hline Copyright infringement plagiarises resources & 5 & 15 & 5 & 8 & 12 \\
\hline I have never seen anywhere this being enforced & 21 & 3 & 1 & 13 & 7 \\
\hline The library does not allow photocopying of the whole book & 18 & 9 & 1 & 2 & 15 \\
\hline Copyright issues are not considered at all in my institution & 11 & 12 & 7 & 3 & 12 \\
\hline Educational institutions often violate copyright laws due to limited budgets & 14 & 9 & 3 & 1 & 18 \\
\hline $\begin{array}{l}\text { Photocopying the whole book without seeking permission from authors is } \\
\text { being done }\end{array}$ & 6 & 6 & 2 & 6 & 25 \\
\hline Photocopying materials without copyright owners is a common vice & 6 & 9 & 3 & 6 & 21 \\
\hline Piracy is counterproductive in that it kills innovativeness & 14 & 1 & 12 & 3 & 15 \\
\hline It is not easy to detect the duplicated work mostly in hard copies & 18 & 5 & 11 & 3 & 8 \\
\hline $\begin{array}{c}\text { Authors fear to share their work in most cases electronically because they } \\
\text { know that it will be plagiarised and thus low moral for publishing }\end{array}$ & 9 & 6 & 2 & 7 & 21 \\
\hline Scanning of academically scholarly work is done wholesale & 6 & 2 & 7 & 11 & 19 \\
\hline Not much is tampered with without IPR & 6 & 6 & 6 & 9 & 18 \\
\hline Digitised materials for library usage never considers copyright & 9 & 9 & 7 & 2 & 18 \\
\hline Copyright activity is not very common and thus less extent considered & 6 & 6 & 14 & 3 & 16 \\
\hline $\mathrm{N}=45$ & & & & & \\
\hline
\end{tabular}

\section{Custodians' views regarding copyright infringement in Uganda}

The third objective of this study was to assess the opinions of the custodians on the practices regarding copyright infringement in Uganda.

a) Position whether photocopying/scanning and duplication have a significant effect on copyright infringement

Respondents were required to support the position that photocopying, scanning or duplicating of academic and non-fiction works have had a great contribution on copyright infringement (economic and moral) of authors. Out of 45 respondents, $33(73 \%)$ said yes while $12(27 \%)$ indicated no.

b) Rating on the opinion on photocopying/scanning and duplication have a significant effect on copyright infringement

A further investigation of why they thought so was done to agree or disagree with the statements. The number of respondents for each of the opinion under each rank is 
presented in table 5, where 1 represented strongly disagree and 5 strongly agree as reported in Table 5 .

Table 5 shows that photocopying, scanning, and digital downloading of academic and non-fiction works have had a great contribution on copyright infringement. Although the custodians are aware that photocopying a whole book is illegal, the vice goes on unimpeded. It is the author's duty to register his/her copyright, keep a record of such copyright, ensure that his/her rights are protected and raise a complaint or seek redress in case of infringement from relevant authorities such as courts of law, the police and collecting societies.

c) Challenges affecting copyright infringement in Uganda

Respondents were asked their views on the challenges affecting piracy in Uganda

Implementation of the law: Although respondents recognised the existence of a law on copyright, they noted that it was poorly enforced as a result of weak regulations, poor infrastructure, the absence of an active piracy monitoring body in Uganda, weak institutions ignorance about the ill effects of piracy and weak policies. Also noted was. The impact of the electronic environment varies: It affects iterative copying to the significant extent and also increases chances of copying without permission, where permission becomes an obstacle.

Legal and regulatory framework: Respondents observed that the copyright law especially the coverage of the policy on piracy in Uganda was not comprehensive. To many, violators were not brought to book so others felt free to do what they wanted. Respondents noted that some institutions and individuals did not know what copyright was and its effects on promotion of the book industry.

Awareness: It was noted that the lack of awareness of copyright laws among leaders and the people who do photocopying, and a poor reading culture in Uganda, has also encouraged copyright infringement. In addition, owners of original works cannot easily tell who has violated their works.

It was also noted that some individuals pirate books for sale. For instance, cases have been reported of an original version and a pirated version of a book being sold at different prices. It is true that authors have not been vigilant with regard to the infringement of their copyright. Indeed, Kawooya, Kakungulu and Akubu 48] give an analysis of various cases in Uganda including one of "John Murray vs. Kampala New Styles Bookshop that demonstrate the rampancy of copyright violations". The authors of the report survey asserted that the Bookshop, which was at the time one of the biggest in Uganda, collapsed as a result of this case. This demonstrates the significant practical effect that copyright can have, if and when it is enforced.

\section{Strategic/policy options for delimiting copyright infringement}

Objective 4 aimed at providing strategic/policy options for delimiting copyright infringement in Uganda. Respondents were requested to rank the strategic/policy options on delimiting the copyright infringement in Uganda. Using a likert scale with the ranks of 1 to 5 , respondents were asked to rate the pre-determined strategic policy actions. The number of respondents for each of the strategic policy options under each rank is presented in table 6 , where 1 is the least favoured and 5 is the most favoured.

Table 6. Ranking of the strategic/policy options on alleviating copyright infringement

\begin{tabular}{|c|c|c|c|c|c|}
\hline \multirow[b]{2}{*}{ Strategic Policy Actions } & \multicolumn{5}{|c|}{ Rankings } \\
\hline & 1 & 2 & 3 & 4 & 5 \\
\hline $\begin{array}{l}\text { The Copyright Collecting Society should ensure effective issuing of a license } \\
\text { that grants anybody the right to copy, use and distribute information }\end{array}$ & 12 & 6 & 2 & 9 & 16 \\
\hline $\begin{array}{l}\text { The Authors' Association -UTANA to enter into, co-ordinate and to sustain } \\
\text { negotiations for contracts, equitable agreement to ensure effective collection } \\
\text { of payment on photocopying from textbooks - academic and non-fiction works } \\
\text { as per the law so established in the country }\end{array}$ & 1 & 4 & 6 & 12 & 22 \\
\hline $\begin{array}{l}\text { UTANA to facilitate interaction, exchange and collaboration as a medium for } \\
\text { debating issues of interest to academic and non-fiction authors across the } \\
\text { different disciplines }\end{array}$ & 3 & 5 & 7 & 12 & 18 \\
\hline $\begin{array}{c}\text { The Government to provide rewards to academic works borrowed from the } \\
\text { library/documentation centres through public lending rights under the } \\
\text { management of copyright collecting societies }\end{array}$ & 3 & 7 & 12 & 4 & 19 \\
\hline $\begin{array}{l}\text { The Government to institute levy system on photocopying (Photocopying } \\
\text { machines and other equipment) for private and personal use to support the } \\
\text { remuneration of authors based on pay per use or annual license. }\end{array}$ & 9 & 15 & 5 & 6 & 10 \\
\hline $\begin{array}{l}\text { UTANA, Collecting Society and Government together to institute a retirement } \\
\text { and/or pension scheme for benefit of authors at their old age. }\end{array}$ & 6 & 3 & 4 & 8 & 24 \\
\hline
\end{tabular}


From table 6 above, it is clear that there is need for strategic alliance and partnership among the various stakeholders - the right holders' organisation, Collecting Society and Government to address issues that benefit authors. On further investigation, the respondents provided the following as the possible strategies for protecting copyright infringement in Uganda:

Awareness and sensitisation programme: It was noted that there was need for an awareness programme about the disadvantages of piracy, penalties for illegal bookshops, the legal provisions and enforcement of the law and the copyright policies in place.

Enforcement: Respondents noted the need for law enforcement by the registering authority for maximum copyright protection. For instance, the copyright office should provide online searching of its registration records whether the owner cares about protection or not, and the penalty should be increased from the current fine of one hundred currency as a deterrent to offenders.

Advocacy: It was noted that there was need for increased alliance and advocacy by authors and stakeholders such as UTANA for copyright protection. For example, whereas the author should endeavour to register his/her copyright works, UTANA could help to monitor if there is any infringements.

Government support and responsibility: It was noted that UTANA should engage the government to make the copyright law known to all institutions both private and government. In addition, the country should levy a tax system on photocopying in order to limit duplication of academic works. A government programme to reward authors shall motivate the writing industry in Uganda.

Uganda Reproduction Rights Organisation (URRO) is mandated to license photocopying, scanning and other digital uses. It therefore follows that educational institutions, libraries and archives of all types are required to pay a license fee to URRO on behalf of the rights holders for the use of copyright works. The funds collected from this scheme are expected to be distributed among the rights holders. To that end, authors shall be remunerated through their rights holders' societies, while at the same time copyright works are accessed and used for educational and fair use purposes. URRO has been involved in confiscating pirated books and enforcing copyright protection since July 2014. In addition, the Uganda Registration Service Bureau (URSB) is introducing the imposition of holograms on books to authenticate them and eliminate illegal reproduction. According to Okia [48] as reported by Monitor, starting September this year, there are plans to introduce holograms (a special type of picture in which the objects seem to be three-dimensional (solid rather than flat) on all genuine books sold in the Ugandan market as a measure to fight against piracy as it will differentiate them from imitations. Apart from helping the buyers ensure they are buying a genuine book, it will also ease the work of inspectors as they rid the market of pirated books. URRO works through rights holders' organisations, such as Uganda Publishers
Association (UPA) and UTANA. The rights holders, through UTANA, have the collective responsibility to advocate for the recognition of their works and protection of their rights, products and services. It is thus the responsibility of an author to join UTANA for gainful authorship efforts.

\section{Synthesis}

This study acknowledges that the Copyright and other Neighbouring Rights Act, 2006 provides for legislation with regards for intellectual rights. However, there are some key concerns that limit authors from fully enjoying the benefits of authorship. A study was carried out to assess the state of copyright infringement in Uganda with the aim of establishing the nature and forms of copyright infringement, identifying the circumstances for copyright infringement and assessing the opinions of the custodians on the copyright infringement in order to provide strategic/policy options for delimiting copyright infringement. Through a survey from the custodians of copyright works, it was established that photocopying, scanning of books and digital and internet downloads have significantly influenced the copyright infringement. The more affected forms were plagiarism, culture creative and piracy. Whereas plagiarism was common in universities by students' research reports, internship reports, research work/reports, papers presented and thesis and dissertations as well as scholarly articles, piracy was common in textbooks. Whereas piracy is rampant, there are no exhibited efforts being done about it, a vice that has greatly affected the publishing industry and may threaten to kill initiatives and creativity, robbing or limiting writers' earnings from their original work.

The increased need for information materials has dictated electronic document delivery and use of digital downloads, especially for teaching and educational purposes. At the same time, e-resources increase exposure to liability for copyright infringement. The complexities of the electronic environment, and the growing potential for implicating copyright infringements, raise the need for a consulted effort to deal with the use of fair use. The continued need for peer to peer communication and sharing needs of information shall continue to demand for making of copies especially for academic purposes. Thus it remains a fact that duplicating and digital downloading of academic and non-fiction works have had a great contribution on copyright infringement for both economic and moral rights of authors. There is also no doubt that libraries and librarians/ custodians are aware that photocopying whole books without seeking permission from authors is illegal. This vice was attributed to weak regulations, weak institutions and poor enforcement of the law and policies. Absence of awareness on the copyright laws by authors, custodians of copyright materials, and implementers has also increased the infringement.

It is thus thought a duty of UTANA, Collecting Society and Government to institute a programme to benefit the authors for their long engagement in authorship. One way was for UTANA to enter into, co-ordinate and to sustain 
negotiations for equitable agreements for its members. Indeed, currently, through the URSB, URRO is introducing hologram, the anti-piracy security techniques to help curb the pirates in the country. The current discussions at WIPO are focusing on the possibility of new copyright exceptions treaties for libraries, archives and education. Therefore, prioritised awareness and sensitisation programme of its stakeholders and increased advocacy and agitation for copyright protection with strengthening strategic alliance shall provide a clear direction for UTANA. One of such breakthrough strategy is to seek for government support with a clear strategic intervention of shared responsibility and benefits with articulated clear benefits and outcomes in meeting the government objectives and society needs. It is thus important that a framework to facilitate a workable path that libraries, custodians of works may follow in order to exercise a meaningful application of fair use, while also acknowledging and respecting the interests of copyright owners. Such strategy shall offer enhanced access to copyright works but ensuring authors that are fairly paid.

\section{Conclusions}

The current un-predictable copyright environment has an impact on author intellectual freedoms and an effect on the economic rights of authors. The existing different licensing systems and copyright protection target the custodians of copyright works to advocate for open access, creative commons and institutional repositories. Increased access to materials without restrictions has resulted in copyright infringement, especially in the works that fall into legal exceptions for fair use in educational institutions and libraries. The extent of copyright infringement can be described as rampant although not being detected due to lack of awareness and laxity in the legal framework implementation. The existing legal framework of exemptions for fair use has on one hand increased access and use of copyright works but on the other hand has limited the copyright owner's expected financial gains. This is why Collecting Society, government and right holders organisations must work together to institute a programme to benefit the authors for their long engagement in authorship. Such programme should integrate awareness and sensitisation of its stakeholders and increased advocacy and agitation for copyright protection with strengthening strategic alliance.

\section{Action Programmes and Way forward}

There is no doubt that whereas there are legal provisions regarding the exemptions on fair use of authors' works, there are un controllable infringement as a result of photocopying, scanning, digital uses otherwise known as secondary uses. Potential market sectors are: the education sector at all levels; libraries of all types e.g. research, public, special; cultural institutions e.g. museums and galleries. To ensure right holders continue enjoy the benefits of their works, one of the tasks to leverage the situation is exemption licencing. This shall enable right holders to enjoy the benefits of orderliness and control to a market where the copying of copyright materials is currently taking place without authorisation. It shall also enable users to copy legally and incentivize authors/publishers; enjoy an additional revenue stream for creators and participate in collective efforts to curb commercial piracy. Funds collected by the Collecting Society so authored by Government shall be distributed as remuneration to rights holders directly through their associations. UTANA is currently engaging its stakeholders including URRO, publishers, National Curriculum Development Centre (NCDC) and institutions for advocating for copyright protection. UTANA shall continue to engage in various activities like workshops, seminars and public talks for increased awareness, sensitisation and advocacy. In addition, UTANA has organised various capacity building workshops to address the needs, competences and skills required by the authors. UTANA is set to engage publishers association and publishers in Uganda in negotiating for standard contracts to be followed by the authors in their publishing process. UTANA is also set to engage in strategic meetings with high level positioned stakeholders, in government, higher education and Vice Chancellors Forum, especially to present a position about licencing of educational institutions. UTANA shall continue to map its presence to the international partners including the International Authors Forum, Norwegian Association of Non-Fiction and Translators (NFF), and Pan African Writer's symposium (PAWS).

\section{Acknowledgements}

This Study was supported by Norwegian Association of Non-Fiction and Translators (NFF).

\section{REFERENCES}

[1] Berkman Center for Internet and Society. 2010. Developing Learning Materials Case Study "Copyright for Librarians" an Online Open Curriculum on Copyright Law developed with the Berkman Center for Internet and Society at Harvard Law School launched in March 2010: Improved with recommendations from the East African School of Library and Information Science (EASLIS), Uganda, 2010.

[2] Center for Genomic Regulations. Intellectual Property (IP) 2013 [cited October 2014]. http://www.crg.eu/en/content/tec h-transfer-tech-transfer-basics/intellectual-property-ip

[3] Intellectual Property Office. 2014. Creative Leicester Shire, Copyright Infringement, Fair Use and Public Interest Exception: High Court Decision of Angella Katatumba v. Anti-Corruption Coalition of Uganda. https://cipitlawstrath. wordpress.com/2014/08.

[4] WIPO. Legal Framework of the Intellectual Property System 
of Uganda. http://www.wipo.int/wipolex/en/outline/ug.html

[5] Long, Roderick T. The Libertarian Case against Intellectual Property Rights. Article, Free Nation Foundation Autumn 1995 [cited September 2014],. http://freenation.org/a/f3111.h tml

[6] Fisher, William. Theories of Intellectual Property. 2012. [Cited October 2014].http://www.law.harvard.edu/faculty/tfi sher/iptheory.html

[7] Weber, Dane Joseph. A Critique of Intellectual Property Rights. Thesis submitted to Dr. Steven Snyder in Candidacy for the Degree of Bachelor of Arts, Department of Philosophy, Christendom. 2002. Cited October 2014. http://dane.weber.org/concept/thesis.html

[8] WIPO. Uganda Patients Act, http://www.wipo.int/wipolex/en /details.jsp?id $=5237$

[9] The Constitution of the Republic of Uganda: Chapter 4: Human Rights \& Freedoms. 2014. http://dredf.org/internatio $\mathrm{nal} /$ UgaConst.html

[10] The Copyright and Neighbouring Rights Act, 2006. DATE OF ASSENT: 31st May, 2006.http://www.ulii.org/ug/legislation /act/2015/2006-24

[11] The Copyright and Neighbouring Rights Regulations, 2010. http://www.ulii.org/ug/legislation/statutory-instrument/2010/ 1

[12] Magezi, Ibale \& Co. Advocates. Copyright Law in Uganda, 2010.

http://www.wakili.co.ug/practice-areas/copyright-protection/ 20-copyright-law-in-uganda

[13] Ministry of Justice and Constitutional Affairs. 2014. http://www.gov.ug/ministry/ministry-justice-and-constitutio nal-affairs

[14] Uganda Registration Service Bureau. Copy Rights. 2014. http://www.ursb.go.ug/index.php?option=com_content\&vie $\mathrm{w}=$ article $\& \mathrm{id}=79 \&$ Itemid $=37$

[15] Uganda National Council for Science and Technology. http://www.uncst.go.ug/about-us.html

[16] National Council for Higher Education.2014.Uganda National Council for Higher Education. http://www.unche.or.ug/about -unche/functions

[17] Kawooya, Dick, Kakungulu, Ronald and Akubu, Jeroline. 2010. Chapter 9: Uganda. Access to Knowledge in Africa: The Role of Copyright. (C Armstrong, J De Beer, D Kawooya, A Prabhala, TSschonwetter (Editors). University of the Witwatersrand: The

[18] Namaganda, Agnes. Institutional Repositories and Higher Education in Uganda: the Role of the Consortium of Uganda University Libraries. http://www.academia.edu/3617835/

[19] Kakai, Miriam. The Challenges of Advocating for Open Access through Institutional Repository Building: Experiences from Makerere University, Uganda. In Library Theory and Research, World Library and Information Congress: 75th IFLA General Conference and Council 23-27 August 2009, Milan, Italy, http://conference.ifla.org/past-wli c/2009/105-kakai-en.pdf

[20] Yu, Peter K.. The Objectives and Principles of the TRIPS Agreement. Law Review 46, forthcoming. http://www.peteryu.com/correa.pdf

[21] IFLA. Internet Manifesto 2014. http://www.ifla.org/publicati ons/node/224

[22] IFLA. The Declaration on Libraries, Information Services and Intellectual Freedom, 2008. http://www.ifla.org/publications/ the-glasgow-declaration-on-libraries-information-services-an d-intellectual-freedom

[23] IFLA. Position on Copyright in the Digital Environment, 2000. http://www.ifla.org/publications/the-ifla-position-on-copyrig ht-in-the-digital-environment-2000

[24] IFLA. 2004. Limitations and Exceptions to Copyright and Neighbouring Rights in the Digital Environment: An International Library Perspective, 2004.

http://www.ifla.org/publications/limitations-and-exceptions-t o-copyright-and-neighbouring-rights-in-the-digital-environm

[25] IFLA. Libraries and archives leave international copyright discussions empty handed after countries again fail to reach agreement. 14 July 2014, http://www.ifla.org/node/8759..

[26] IFLA Limitations and Exceptions to Copyright and Neighbouring Rights in the Digital Environment

[27] Long, Roderick T. The Libertarian Case against Intellectual Property Rights. Article, Free Nation Foundation Autumn 1995 [cited September 2014],. http://freenation.org/a/f3111.h tml.

[28] IFLA. IFLA Licensing Principles, 2001. http://www.ifla.org/publications/ifla-licensing-principles-20 01

[29] Besek, June M. Etail 2008. Digital Preservation and Copyright: An International Study, the International Journal of Digital Curation, 2(3), 103-111, 2008.

[30] PLR International. frequently asked questions. http://www.plrinternational.com/faqs/faqs.htm\#plr

[31] Falvey, Rod. The Role of Intellectual Property Rights in Technology Transfer and Economic Growth, Theory and Evidence, Vienna, 2006: Leverhulme Centre for Research on Globalisation and Economic Policy, School of Economics, The University of Nottingham: Strategic Research and Economics Branch

[32] Fisher, William. Theories of Intellectual Property. 2012. [Cited October 2014].http://www.law.harvard.edu/faculty/tfi sher/iptheory.html

[33] Hyalt, Dennis. Legal Aspects of Public Lending Right/. https://www.ideals.illinois.edu/bitstream/handle/2142/7171/1 ibrarytrendsv29i4d_opt.pdf?sequence $=1$ Consequences of Plagiarism. http://www.ithenticate.com/resources/6-consequ ences-of-plagiarism

[34] Muwanga, David. Bitamazire calls for Liberal Copyright Law, New Vision. Publish Date: Dec 17, 2005.http://www.newvis ion.co.ug/D/9/35/471710

[35] Open Rights Group. Trade-Related Aspects of Intellectual Property Rights. 3 August 2013, https://wiki.openrightsgrou p.org/wiki/Trade-Related_Aspects_of_Intellectual_Property _Rights

[36] Berkman Center for Internet and Society. Developing Learning Materials Case study "Copyright for Librarians" an Online Open Curriculum on Copyright Law developed 
with the Berkman Center for Internet and Society at Harvard Law School launched in March 2010: Improved with recommendations from the East African School of Library and Information Science (EASLIS), Uganda

[37] World Intellectual Property Organization. Berne Convention for the Protection of Literary and Artistic Works. Amended on September 28, 1979, Entry into force on November 19, 1984.http://www.wipo.int/wipolex/en/wipo_treaties/details.j sp?treaty_id=15

[38] The Copyright and Neighbouring Rights Act, DATE OF ASSENT: 31st May, 2006.http://www.ulii.org/ug/legislation /act/2015/2006-24

[39] IFLA. Libraries and Archives Leave International Copyright Discussions Empty handed after Countries again fail to reach Agreement, 14 July 2014, . http://www.ifla.org/node/8759.

[40] Nassaka, Flavia. Uganda: Plagiarism to Blame for Poor Quality Graduates, All Africa, 13th August 2012.http://allafrica.com/stories/201208131189.html,

[41] Uganda Technology and Management University (UTAMU). Dons Caution PhD Students Against Plagiarism (UTAMU), 2014. http://utamu.ac.ug/latestnews/796-dons-caution-phd-st udents-against-plagiarism.html

[42] Ugandan anti-piracy operation nets 80,000 books. http://www.ifrro.org/content/ugandan-anti-piracy-operationnets-80000-books

[43] Weekly Observer. Plagiarism a Cancer at Makerere - Professor, 2009. http://observer.ug/index.php?option=com_content\&vi ew=article \&id=2134:plagiarism-a-cancer-at-makerere-profes sor\&catid=34:news\&Itemid $=114$

[44] Prof. George. W. Kakoma v The Attorney General. Free Access to Ugandan Law. Submitted by Mariya on 3 February 2012 - 10:43am. http://www.ulii.org/ug/judgment/high-court $12010 / 40$

[45] Ugandan anti-piracy operation nets 80,000 books. http://www.ifrro.org/content/ugandan-anti-piracy-operationnets-80000-books

[46] The Copyright Act, 2001, No. 12 of 2001, Kenya Gazette Supplement No. 97 (Acts No. 10), Printed and Published by Government Printer, Nairobi.

[47] Danish. DU students photocopying academic books is legal. Aug 31, 2012 15:10 IST. First post. http://www.firstpost.co $\mathrm{m} /$ india/du-students-photocopying-academic-books-is-legal437852.html

[48] Book piracy: The evil killing reading culture, publishing. http://www.monitor.co.ug/artsculture/Entertainment/Book-pi racy--The-evil-killing-reading-culture--publishing/-/812796/ 2388956/-/v9dy9kz/-/index.html 